\title{
Minority Muslim Communities in Post-Bipolar Europe (Western Europe \& the Balkans)
}

\author{
23-25 Rabì al Thänī 1415 / 28-30 September 1994 \\ Amman, Jordan
}

A conference on Minority Muslim Communities in Post-Bipolar Europe (Western Europe \& the Balkans), convened by the Centre for Middle Eastern and Islamic Studies at the University of Durham (UK), was held at the Regency Palace Hotel in Amman at the invitation of the Royal Academy for Islamic Civilisation Research (Al AIBait Foundation). It was funded largely by Jordanian governmental sources on the instruction of HRH Crown Prince Al-Hassan, who has a particular interest in the conference theme, and who extended his royal patronage to the event. Modest contributions towards expenses were also forthcoming from the World Assembly of Muslim Youth (Riyadh, Saudi Arabia), and L'Institut European des Sciences Huamines (Saint-Leger-de-Pougeret, France).

Attended by some thirty-five researchers and activ-ists, this conference was the third in a series initiated by British academics. The first two were held during 1993 in Skopje (FYROM) and Durham (UK), and were sponsored by the British Council and the Council of Europe. This one differed from its predecessors in a number of ways. For the first time, an attempt was made to provide a forum for exchange between European researchers in this field and their colleagues from the various European Muslim communities examined. An effort was also made to cut across social scientific, political, and human rights discourses.

The conference was inaugurated by Suha Taji-Farouki (Centre for Middle Eastern and Islamic Studies, University of Durham), the Conference Convener; Mani' al-Johani (Secretary-General, World Assembly of Muslim Youth); Ahmad Maballah (Director of Academic Affairs, L'Institut European des Sciences Humaines); and by HRH Crown Prince Al-Hassan, delivered on his behalf by HE Professor Nassir El-Din EIAssad (President, Royal Academy for Islamic Civilisation Research, Al AlBait Foundation). Each speaker highlighted the importance and timeliness of the conference, in light of the USSR's and Yugoslavia's disintegration and the growing strength of movements inimical to North African, Middle Eastem, and Asian Muslims in western Europe. Speakers also pointed to the popular notion of a so-called civilizational conflict between Islam and the West, positing Europe's relations with its Muslim commu- 
nities as a critical testing ground for the future direction of relations between Islam and the West in general.

The conference opened with a general paper by Saleha S. Mahmood, (Director, Institute of Muslim Minority Affairs, London/Jeddah). She analyzed the predicament faced by Muslim communities in Europe in the aftermath of the demise of bipolarity and discussed the actual and potential responses of the ummah to this predicament.

The first working session addressed three focal themes on the basis of case studies drawn from the five western European countries with the most significant Muslim communities in terms of percentage of the population (Britain, France, Germany, the Netherlands, and Belgium). It was introduced by Felice Dassetto (Universite Catholique de Louvain, Belgium), who presented a series of hypotheses and models for the Muslim presence in western Europe and addressed the past and the future of this presence. The first theme discussed focused on the nation-state, national identity, political participation, and citizenship. Jeroen Doomernik (Free University of Berlin, Germany/University of Amsterdam, the Netherlands) presented a comparative analysis of the relationship between state, politics, and the process of Islamic institutionalization among Turks in the Netherlands and Germany. Jochan Blaschke (Berliner Institut für Vergleichende Sozialforschung, Germany) focused on Germany and analyzed Islam's status as a minority and diaspora religious phenomenon in a quasi-secular state. Thilij Sunier (Free University of Amsterdam, the Netherlands) examined relations between Muslim organizations and the local urban community in the Dutch context, using Rotterdam as a case study. James House (Leeds University, UK) discussed the "space" of Muslim identities in contemporary French society and analyzed the way in which Muslim identities there have been portrayed in political discourse as incompatible with "French identity.” Ahmad Jaballah ((L'Institut European des Sciences Humaines, France) examined the issue of Muslim integration in the French context. Yahya (Jean) Michot (University of Louvain, Belgium) discussed the Higher Council of Muslims of Belgium, which he upheld as a shürä experience in the of Europe. Christopher Hewer (Centre for the Study of Islam and Christian-Muslim Relations, Birmingham, UK) discussed relevant recent developments among Muslims in England.

The second focus addressed the interrelated issues of mutual perceptions and the media. Ibrahim al-Shamsi (United Arab Emirates University, UAE) began with a general discussion of the media image of Muslim minorities in the West, focusing on the case of Muslims of Arab origin. Abdul Wahid Van Bommel (Dutch Muslim Broadcasting Foundation, Hilversum, the Netherlands) explored the role of the mass media in communication between Muslims and non-Muslims and used the metaphor of "mirror image thinking" to analyze mutual image forming among Muslims and non-Muslims. The focus concluded with a discussion of German media and governmental perceptions of Islam and Muslims, presented on behalf of Muhammad Aman Hobohm (writer and activist, Bonn, Germany). 
The third focus addressed the international dimension and featured papers by Nico Landman (University of Utrecht, the Netherlands) and John King (BBC Arabic Service, London, UK). Landman discussed the attempts of the Directorate of Religious Affairs in Ankara to influence the identity of Turkish Muslims in western Europe, while King examined British Muslim views of international political issues as expressed in the English language Muslim media in England.

The second working session examined the Balkans. Robert Hickey (Institute for East/West Studies, Prague, Czech Republic) began with a general assessment of the political importance of the religious affiliation of Muslim minorities in the context of Balkan security. The first theme addressed Muslim identity under communism and Islam's renaissance since the collapse of communism. A case study of Albania was presented by Genc Lamani (BBC Albanian Service, London, UK) and Elira Cele (University of Tirana, Albania). The second focus considered changing notions of national identity and citizenship and Islam's role in the reconstruction/resurgence of ethnic/national identity. Hugh Poulton (London University, UK) examined the changing national identity of Muslim minorities in the FYROM, Bulgaria, and Greece. Baskin Oran (University of Ankara, Turkey) dealt with Kosova, Yulian Konstantinov (University of Sofia, Bulgaria) examined the Bulgarian Pomaks and discussed strategies for maintaining a vulnerable identity, and Wolfgang Bopken (University of Leipzig, Germany) analyzed ethnic identity among the Turks of Bulgaria before, during, and since communism. Isa Zymbari (Director, Kosova Information Centre, London, UK) examined ethnicity in the former Yugoslavia and focused on Kosova. Zahid Mukhanovic (Bosnian Information Bureau, Amman, Jordan) examined Bosnia. The session ended with two general papers by Sadik Ahmet (Former Muslim deputy in the Greek Parliament, Konotini, Greece) on the human rights situation of the Turkish Muslim minority in western Thrace, and Mustafa Kahramanyol (Advisor to the Prime Min-ister of Turkey, Ankara) on the educational circumstances of Balkan Muslim communities.

A third working session introduced non-European comparisons. Iqbal Jhazbhay (University of South Africa, Pretoria) examined contemporary Islamic discourse in South Africa from apartheid to post-apartheid Islam. Michael Dillon (Department of East Asian Studies, University of Durham) discussed Islam in contemporary China and raised questions about possible parallels with Europe.

It was noted during the closing session that the conference had provided a rare and rich opportunity for exchange, afforded by the varied backgrounds, disciplines, and approaches of the participants. While some reservations were expressed concerning the clashes that can arise between the three types of discourse represented at the meeting, it was generally agreed that the experiment had been fruitful.

It was suggested that more effort should be made in the future to discover or develop paradigms applicable to more than one region in order to adopt a comparative approach. In this respect, participants expressed espe- 
cial appreciation for the inclusion of non-European experiences. Notes were exchanged on the possible shape, focus, and discursive paradigms of future conferences on the theme, and practical details on funding, location, and related matters were discussed. A small follow-up committee was established to direct the preparation of a selection of papers from the conference proceedings for publication in England. This committee is coordinated by Suha Taji-Farouki, who can be reached at:

CMEIS, University of Durham South End House, South Road Durham, DH1 3TG, UK Tel: 44-1-374-2827 (direct line)/2822 (messages) Fax: 44-91-374-2830 